\title{
Dangerous anaphylactic reaction to mustard
}

Krzysztof Pałgan, Magdalena Żbikowska-Gotz, Zbigniew Bartuzi

Department of Allergology, Clinical Immunology and Internal Diseases, Collegium Medicum of L. Rydygier in Bydgoszcz, Nicolaus Copernicus University in Torun, Poland

Submitted: 9 September 2015

Accepted: 21 October 2015

Arch Med Sci 2018; 14, 2: 477-479

DOI: 10.5114 /aoms.2016.60580

Copyright @ 2016 Termedia \& Banach

Food allergy is an important health problem and affects between $2 \%$ and $10 \%$ of the general population. In Europe it ranges from $0.1-3.2 \%$ for adults and $0.1-5.7 \%$ for children. According to the epidemiological data the prevalence of food allergy is increasing. Most cases of food allergy are associated with cows' milk, hens' eggs, peanuts, tree nuts, soy, wheat, shellfish and fish [1]. The European list of potentially dangerous allergens contains: cereals containing gluten, crustaceans, mollusks, eggs, fish, peanuts, tree nuts, soybeans, milk, celery, mustard, sesame, lupin and sulfur dioxide [2]. Food allergy can be IgE-mediated or non-IgE-mediated. IgE-mediated reactions have a rapid onset, affecting the skin, respiratory tract, and gastrointestinal tract, and in some cases can lead to systemic anaphylaxis, whereas non-lgE-mediated food allergy usually is delayed and affects mainly the skin and the gastrointestinal tract [3].

We report the case of a patient who experienced a severe anaphylactic reaction immediately after the ingestion of mustard.

A 38-year-old Caucasian woman ate sausage with mustard sauce. Within minutes, she was feeling dizzy and rapidly developed dyspneic symptoms with tightness of her chest, wheezing, and nausea, and subsequently she became unconscious. Following that, she developed widespread urticaria with pruritus. The examination in the hospital confirmed tachycardia of $135 / \mathrm{min}$ and blood pressure of $65 / 45 \mathrm{~mm} \mathrm{Hg}$. After she had been treated with adrenaline i.m., intravenous saline hydration, anti-histamine antihistamines and steroids gradual improvement was observed.

Having performed examinations after recovery from anaphylactic shock, except for stomach inflammation detected by upper gastrointestinal (UGI) endoscopy, ECG and spirometry were normal. No abnormal findings were noted on the chest X-ray and paranasal sinuses.

The complete blood count revealed hemoglobin, $16.8 \mathrm{~g} / \mathrm{dl}$; hematocrit, 49.1\%; leucocytes, $11.69 \times 10^{3} \mathrm{ml}$; neutrophils, $7.4 \mathrm{G} / \mathrm{l}$; lymphocytes, $1.0 \mathrm{G} / \mathrm{l}$; eosinophils, $0.03 \mathrm{G} / \mathrm{l}$; monocytes $0.34 \mathrm{G} / \mathrm{l}$ and platelets, 367 000. She had no known food or drug allergies, but had seasonal allergic rhinitis in spring. Serum total IgE was $42.87 \mathrm{IU} / \mathrm{ml}$ and specific IgE determinations were remarkably positive to grass pollen $(17.37 \mathrm{IU} / \mathrm{l})$. Skin prick tests with common aeroallergens were positive to grass pollen. A strong skin prick test response was obtained with mustard allergens. Flow cytometry was normal.

The patient was instructed to avoid mustard sauce and seeds, including reading food labels, and was prescribed an epinephrine autoinjector.

There are two major types of mustard seeds: white (Sinapis alba $L$, or yellow mustard) and brown (Brassica juncea L, or oriental mustard).

\author{
Corresponding author: \\ Krzysztof Pałgan MD \\ Department of Allergology, \\ Clinical Immunology \\ and Internal Diseases \\ Nicolaus Copernicus \\ University \\ Collegium Medicum \\ 75 Ujejskiego St \\ 85-168 Bydgoszcz, Poland \\ Phone: +48523655416 \\ Fax: +48 523484076 \\ E-mail:palgank@wp.pl
}


Sinapis alba, known as yellow mustard, is commonly consumed as a mustard sauce and added as a hidden condiment in many sauces and salad dressings in Europe [4-6]. However, very few cases of mustard seed-induced allergic reactions have been reported (Table I). Apart from celery, sesame, lupine, and shellfish, mustard is one of the most frequent spices causing IgE-mediated severe anaphylaxis. The mustard allergens are shown in Table II $[4,7]$.

The present report shows that mustard can cause a life-threatening reaction. A variety of food reactions caused by mustard have been reported in the literature. Cuervo-Pardo et al. have described facial flushing, lower extremity urticar- ia, chest tightness and vomiting within $30 \mathrm{~min}$ of eating quinoa - a dish with mustard [7]. Some authors observed allergic contact dermatitis after exposure to mustard, while other authors observed the relationship between ingestion of mustard and atopic dermatitis severity [8, 9].

Approximately $50 \%$ of patients with mustard allergy are also sensitized to mugwort pollen and various foods of the Rosaceae family, nuts, and legumes [10].

Our patient has a history of pollen allergy and was diagnosed with IgE-mediated mustard-induced anaphylaxis. The time course of her allergic symptoms was correlated with the type I reaction according to Gell and Coombs. As well as high al-

Table I. Some reported cases of allergic reactions induced by mustard

\begin{tabular}{|c|c|c|c|c|c|}
\hline Case & $\begin{array}{l}\text { Age/ } \\
\text { Gender }\end{array}$ & Symptoms and signs & $\begin{array}{l}\text { History of food } \\
\text { allergy and allergic } \\
\text { disease }\end{array}$ & $\begin{array}{l}\text { Positive reactions to skin tests } \\
\text { and/or serum specific IgE }\end{array}$ & Reference \\
\hline 1 & $38 / F$ & Anaphylactic shock & Allergy to mustard & $\begin{array}{l}\text { Skin prick tests positive to } \\
\text { mustard, coriander, and curry } \\
\text { powder which contain mustard }\end{array}$ & {$[6]$} \\
\hline 2 & $47 / F$ & $\begin{array}{l}\text { Urticarial, facial } \\
\text { angioedema nausea, } \\
\text { vomiting, dyspnea, } \\
\text { wheezing, chest } \\
\text { tightness hoarseness }\end{array}$ & $\begin{array}{l}\text { Seasonal } \\
\text { rhinoconjunctivitis } \\
\text { allergy to mustard }\end{array}$ & $\begin{array}{l}\text { Positive skin tests with grass and } \\
\text { olive pollen. } \\
\text { Serum specific IgE against } \\
\text { mustard strong positive } \\
(23.6 \mathrm{kU} / \text {, class } 4)\end{array}$ & [4] \\
\hline 3 & $15 / F$ & $\begin{array}{l}\text { Urticaria, facial and } \\
\text { throat swelling, chest } \\
\text { tightness }\end{array}$ & $\begin{array}{l}\text { Rhinoconjunctivitis, } \\
\text { asthma }\end{array}$ & $\begin{array}{l}\text { Serum specific IgE against } \\
\text { mustard positive }(18.5 \mathrm{ku} / \mathrm{l}]\end{array}$ & [4] \\
\hline 4 & $48 / F$ & $\begin{array}{l}\text { Allergic contact } \\
\text { dermatitis }\end{array}$ & Not recorded & $\begin{array}{l}\text { Patch test with mustard seed - } \\
\text { positive (erythema and bulla) }\end{array}$ & [13] \\
\hline 5 & $25 / M$ & $\begin{array}{l}\text { Allergic contact } \\
\text { dermatitis }\end{array}$ & Lack of data & $\begin{array}{c}\text { Patch test - positive with } \\
\text { mustard oil at the concentrations } \\
0.05 \%, 0.1 \%, 0.5 \%, 1 \% \text { and } 5 \%\end{array}$ & [14] \\
\hline 6 & $38 / F$ & $\begin{array}{l}\text { Severe anaphylaxis } \\
\text { after eating hidden } \\
\text { mustard }\end{array}$ & $\begin{array}{l}\text { Positive history of } \\
\text { allergy to mustard }\end{array}$ & $\begin{array}{l}\text { Skin prick tests positive to } \\
\text { mustard, ige-specific antibody } \\
\text { against mustard positive } \\
(56.3 \mathrm{ku} / \mathrm{l})\end{array}$ & [6] \\
\hline
\end{tabular}

Table II. Characteristics of mustard allergens

\begin{tabular}{|c|c|c|c|}
\hline Allergen & Properties & Cross-reactivity & References \\
\hline $\begin{array}{l}\text { Sin a } 1 \text { ( } 2 \text { S albumin } \\
\text { seed storage proteins) }\end{array}$ & $\begin{array}{c}14 \text { kDa, } \\
\text { - major allergen } \\
\text { - diagnostic marker } \\
\text { - has eight isoforms } \\
\text { - stable after heating } \\
\text { - resistant to gastric } \\
\text { digestion }\end{array}$ & & {$[10,11]$} \\
\hline Sin a 2 (11S globulin) & $\begin{array}{c}51 \mathrm{Da} \\
\text { IgE-cross reactivity }\end{array}$ & $\begin{array}{l}\text { Pru du 6, Cor a 9, Ara h 3, } \\
\text { Jug r 4, } \\
\text { Pis v 2, glycinins G1-G2, Ber e 2, } \\
\text { Ana o 2, Ses i 6, Car i } 4\end{array}$ & {$[10-12]$} \\
\hline $\begin{array}{l}\text { Sin a } 3 \text { (nonspecific } \\
\text { lipid transfer protein, } \\
\text { LTP) }\end{array}$ & $\begin{array}{c}12 \mathrm{kDa} \\
\text { - resistant to gastric } \\
\text { digestion }\end{array}$ & $\begin{array}{l}\text { Peach, melon, } \\
\text { Artemisia vulgaris }\end{array}$ & {$[10,12]$} \\
\hline Sin a 4 (profilin) & $13-14 \mathrm{kDa}$ & Peach, melon & {$[12]$} \\
\hline
\end{tabular}


lergenic potency of mustard, it seems likely that there was cross-reactivity with grass pollen.

Allergy to plant food allergens is a significant health problem because of the high frequency of systemic allergic reactions. It is the most common cause of fatal and near-fatal food-induced anaphylaxis [11]. Proteins such as R-10 type proteins, lipid transfer proteins (LTPS), inhibitors of protease, chitinases, and $\alpha$-amylases, peroxidases, profilins, vicilins, seed storage proteins, conglutins, glycinins, $\beta$-conglycinins, thiol-proteases and lectins are known cross-reactive allergens. Individuals allergic to tree, grass and weed pollens can develop symptoms ranging from the oral allergy syndrome (OAS) to anaphylactic shock after digestion of plants containing these proteins [12].

Nuts, mustard, soy, lupine and other allergenic plants could also have severe health consequences for consumers due to the hidden exposure [13, 14]. Therefore, it is important to label food with a legal obligation to declare certain food allergens. Patients should be educated on how to recognize the symptoms. They should also be trained in how to treat allergic reactions using an adrenaline autoinjector.

\section{Conflict of interest}

The authors declare no conflict of interest.

\section{References}

1. Sicherer SH, Munoz-Furlong A, Godbold JH, Sampson HA. US prevalence of self-reported peanut, tree nut, and sesame allergy: 11-year follow-up. J Allergy Clin Immunol 2010; 125: 1322-6.

2. European Community. Commission Directive 2006/142/ EC of 22 December 2006 amending Annex IIIa of Directive 2000/13/EC of the European Parliament and of the Council listing the ingredients which must under all circumstances appear on the labelling of foodstuffs. Off J Eur Union 2006; L368: 110-1.

3. Pesek RD, Jones SM. Anaphylaxis in food allergy. Chem Immunol Allergy 2015; 101: 191-8.

4. Vidal C, Díaz C, Sáez A, Rodriguez M, Iglesias A. Anaphylaxis to mustard. Postgrad Med J 1991; 67: 404.

5. Pałgan K, Götz-Żbikowska M, Tykwińska M, Napiórkowska K, Bartuzi Z. Celery-cause of severe anaphylactic shock. Postepy Hig Med Dosw (Online) 2012; 66: 132-4.

6. Kanny G, Fremont S, Talhouarne G, Nicolas JP, MoneretVautrin DA. Anaphylaxis to mustard as a masked allergen in "chicken dips". Ann Allergy Asthma Immunol 1995; 75: 340-2.

7. Cuervo-Pardo L, Gonzalez-Estrada A, Fernandez J. Anaphylaxis after home-made quinoa dinner: hold the mustard. BMJ Case Reports 2015; doi: 10.1136/bcr-2014208980

8. Dannaker CJ, White IR. Cutaneous allergy to mustard in a salad maker. Contact Dermatitis 1987; 16: 212-4.

9. Mailhol C, Giordano-Labadie F, Lauwers-Cances V, Ammoury A, Paul C, Rance F. Point prevalence and risk factors for food allergy in a cohort of 386 children with atopic dermatitis attending a multidisciplinary derma- tology/paediatric allergy clinic. Eur J Dermatol 2014; 24 : 63-9.

10. Sirvent S, Palomares O, Cuesta-Herranz J, Villalba M, Rodriguez R. Analysis of the structural and immunological stability of $2 \mathrm{~S}$ albumin, nonspecific lipid transfer protein, and profilin allergens from mustard seeds. J Agric Food Chem 2012; 60: 6011-8.

11. Hummel M, Wigger T, Brockmeyer J. Characterization of mustard $2 \mathrm{~S}$ albumin allergens by bottom-up, middle-down, and top-down proteomics: a consensus set of isoforms of Sin a 1. J Proteome Res 2015; 14: 1547-56.

12. Sirvent S, Palomares O, Vereda A, Villalba M, CuestaHerranz J, Rodríguez R. nsLTP and profilin are allergens in mustard seeds: cloning, sequencing and recombinant production of Sin a 3 and Sin a 4. Clin Exp Allergy 2009; 39: 1929-36.

13. Li J, Jin HZ. Allergic contact dermatitis caused by Chinese herbal medicine, white mustard seed. J Dermatol 2013; 40: 69-70.

14. Zawar V. Pityriasis rosea-like eruptions due to mustard oil application. Indian J Dermatol Venereol Leprol 2005; 71: 282-4. 